放射光による X 線回折（3）

\title{
$\mathrm{X}$ 線トポグラフィ
}

\author{
河田洋 \\ 高エネルギー物理学研究所, 放射光実験施設 $\mathbf{7} 305$ 茨城県筑波郡大穂町上原 1-1
}

(1986 年 2 月 4 日 受理)

\section{X-ray Topography}

\section{Hiroshi KAWATA}

Photon Factory, National Laboratory for HighEnergy Physics

1-1 Uehara, Oho-machi, Tsukuba-gun, Ibaraki-ken, 305

(Received February 4, 1986)

\begin{abstract}
This paper shows the present status of experimental apparatus and the results from synchrotron radiation (SR) X-ray topography at Photon Factory in KEK. The real time observation by using $\mathrm{X}$-ray TV can be achieved at SR X-ray topography, so the main purpose of these experiments is to get information on dynamic behavior; for example melting and growth processes, phase transitions and etc. The typical experiments for such subjects are described. Recently, monochromatic X-ray topography was tested by using wiggler beam line, and it was confirmed that the real time observation could be also achieved and that the sample heating from the radiation of X-ray beam was negligibly small at monochromatic X-ray topography.
\end{abstract}

\section{1.はじめに}

単結晶中に存在する格子欠陥（転位, 皘層欠陥, 双晶 面, 不純物の析出, 偏析など) や, 誘電体・磁性体の分 域構造などをそれぞれの空間的場所の情報を含んだま ま, 結晶を破壊するととなく回折コントラストの違いと して, 視覚的に観察する方法をX線トポグラフィと呼 ぶ。一般の物性測定は空間的には平均構造の測定となる 場合が多いのに対し，X線トポグラフィは分解能 $(1 \sim 2$ $\mu \mathrm{m})$ の範囲内で結晶の各場所場所での構造の違いを知 ることができる測定法である。

その様な特色を持ったX線トポグラフィは以下の様な 研究に応用されている。

1) 単結晶育成のその場観察と結晶評価

格子欠陥が非破壊に観察できるととから育成結晶の評 価, 特に育成条件を変えた時の評価が半導体結晶を中心 に行なわれている。また単結晶の成長のその場観察もそ の大きな応用の一面であり, 後で紹介する様に GaAs, また $\mathrm{Fe}-3 \% \mathrm{Si}$ 等の結晶成長に関する多くの知見を与 えている。

2）分域構造の観察と相転移
誘電体や磁性体の分域はその自発歪みや磁歪のために それぞれの分域間でその結晶格子がわずかに歪んでいる (歪の大きさ $\approx 10^{-4} \sim 10^{-6}$ )。乙の歪みの大きさはちょう ぞX線回折の反射幅と比較して同程度もしくはそれ以上 であるため, 回折コントラストが生じトポグラフ像とし て観察するととが出来る。また固相一固相の相転 移 む, 相転移に伴ない結晶構造の変化を伴うためその応用対象 となっている。水晶の中間相の観察 ${ }^{1,2)}$ で代表される様 にX線トポグラフィは結晶の場所場所の変化をとらえて いるため, 平均的な結晶構造測定では捕えにくい相（中 間相）が比較的簡単にかつ明確に捕えられるという特徽 を持っていると言えよう。

さて，放射光を用いたトポグラフィの実験は，高エネ ルギー研・放射光実験施設のリングに電子が回るや否や 開始し，「高速X線トポグラフィ」ワーキンググループ により装置の立上げが行なわれた。その結果，現在では ほとんど全ての結晶に対して白色X線トポグラフィを用 いてX線 TV を用いたその場観察を行うととができる 様になった。また最近ウィグラーラインのモノクロメー 夕と組合せた単色 X線トポグラフィの試みがテストさ れ，その結果強い反射を用いればX線 TV によるその 
場観察も可能であるととが明らかとなった。

この紙面では, 放射光を用いたX線トポグラフィの実 験の中からその数例を御紹介しながら，その現状を報告 する。

\section{2. 放射光トポグラフィの特徵について}

放射光トポグラフィと従来のそれとを比較してみると 著しく異なる所は以下に示す強度・白色性・指向性であ る。

\section{1 強 度}

$2.5 \mathrm{GeV}, 150 \mathrm{~mA}$ のリングカレントの時に, 偏向電 磁石から出る放射光の強度は, $60 \mathrm{~kW}$ 級のモリブデン 回転対陰極の特性 $\mathrm{X}$ 線 $(\mathrm{MoK} \alpha)$ と比較して約 1 析強く, ウィグラーラインになるとさらに1桁強い。とのととか らX線 TV を用いたその場観察が主流となり, その研 究対象屯動的過程を追いかけるものが大半をしめる様に なった。

\section{2 白 色 性}

偏向電磁石から出る放射光の内, $\mathrm{X}$ 線ビームラインの 実験ステーションで利用できる波長範囲は $0.3 \sim 3.5 \AA$ 程度である。乙れは短波長側はもともとのスペクトルで 限られており，一方長波長側はビームライン中の 2 枚の $\mathrm{Be}$ 板 (合計 $0.4 \mathrm{~mm}$ 厚) による吸収によっている。

白色 X線トポグラフの大きな特長は上記の波長範囲の X線がサンプルを照射し，あう一つの特色である指向性
と相い合わさって連続X線が作るラウエスポットそのむ のが良質のトポグラフ像となることである。したがって 異なった反射指数の同時観察を容易に行なうことが出 来，また連続波長をひろいてめるため少々結晶性が悪い サンプルであトポグラフ像を観察することが可能とな る。

しかしての特色は逆にサンプルからの蛍光線を励起し バックグラウンドの上昇をま标き，またX線照射による サンプルの温度上昇をまねく。特に $0.1^{\circ}$ 以上の温度コ ントロールが必要な場合には白色X線トポグラフでは観 察が難しく, 後述する単色X線卜ポグラフを用いて初め てうまく観察できることが最近明らかになっている。

\section{3 指 向 性}

放射光実験施設では発光点と実験ステーションまでの 距離が約 $40 \mathrm{~m}$ あるために, 試料と検出器を数 $10 \mathrm{~cm}$ 離 したとしてあ著しい分解能の劣化が生じない。したがっ て試料回りには空間的余裕ができ, 高温, 低温, 磁場印 加などの実験が行われている。

\section{3. 実 験 装 置}

白色X線トポグラフィの実験は主に Fig. 1 で示すト ポグラフィゴニオメータを用いて行われている。てれに ついての詳細は別の論文泉 に記してあるので，ここでは 簡単にしておく。

全体の構成物品を罒の番号順に説明すると，先ず 1 ,

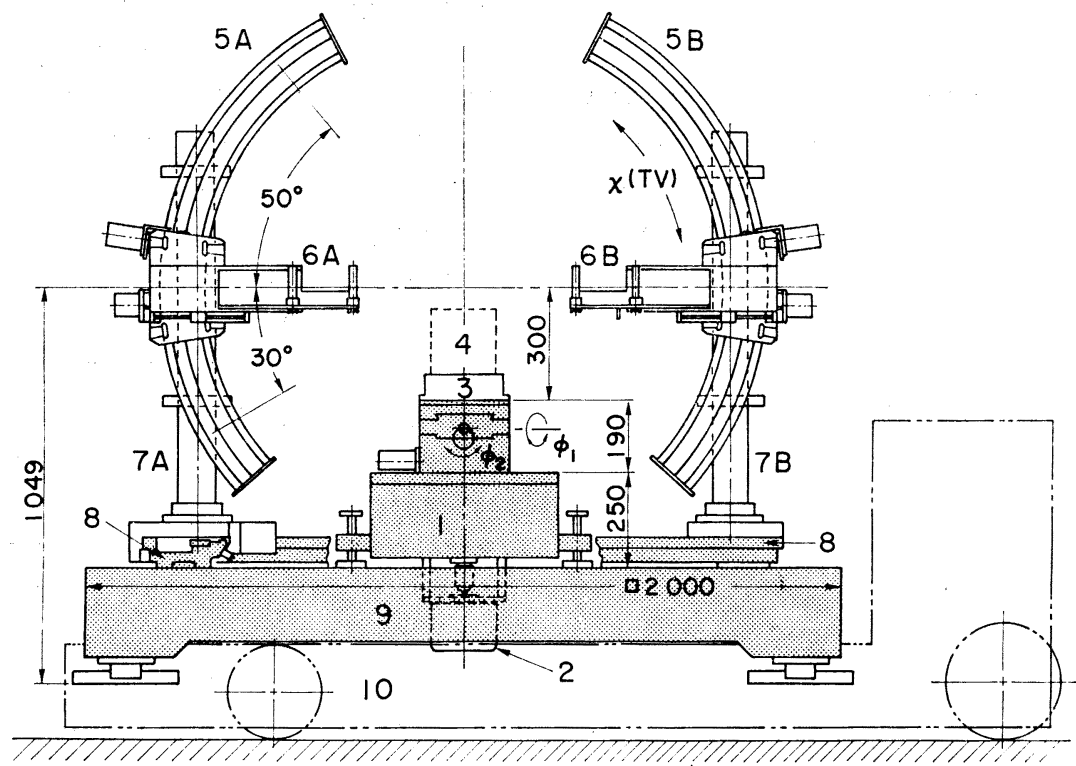

Fig. 1 Goniometer for X-ray topography. $1: \theta, \phi_{1}, \phi_{2}$-goniometer. 2 : Encoder. 3: Translation stage. 4: Goniometer head, heater and cryostat etc. (5A,6A, 7A), (5 B, 6 B, 7 B) : TV camera holders. 8: Ring gear. 9: Steel base plate. 10 : Carriage. 
2,3,4 はサンプル回りのあのでそれぞれ $1: 30 \mathrm{~kg}$ 耐荷 重の $\theta, \phi_{1}, \phi_{2}$ の軸の回転ゴニオメータ, 2 : 回転角 $(\theta$ 軸)を 1 秒の精度でモニタするエンコーダ, $3:$ サンプル を並進運動させるトランスレーションステージ, $4:$ サン プル回りの環境变化を与える装置, たとえばクライオス タットとか高温炉のためへの空間である。5 A, $6 \mathrm{~A}, 7 \mathrm{~A}$ 及び $5 \mathrm{~B}, 6 \mathrm{~B}, 7 \mathrm{~B}$ はそれぞれ 8 で示す施回レール上に 位置する 2 組の X線 TV カメラ (カウンタ) ホルダであ る。それぞれのカメラホルダへは一般にはX線 TV ${ }^{4,5)}$ が登載されているが, 磁気散乱の実験 ${ }^{6)}$ の様に SSD 等 のフォトンカウンターを登載しての実験も行える様にな っている。以上の品物は 9 で示す定盤上に登載されてお り，その全荷重は約 $5 \mathrm{t}$ である。実験ステーションを变 える場合は 10 で示す台車を用いて，ハッチへの搬入搬 出が可能となっている。その他コリメータ及びシャッタ があり，適当なビームサイズを選ぶてとが可能である。 また全ての駆動はパルスモータで行っており, それらは ルーコンピュータでコントロールしている。また実験の具
体的な進め方については別論文? に記してあるのでそち らを参照願いたい。

\section{4. 実 験 例}

Table 1 は過去及び現在に渡って放射光を用いて行わ れた実験課題をまとめたあのである。とこではその中の いくつかを紹介する。

\section{$4.1 \mathrm{GaAs}$ の融解及び成長過程}

$\mathrm{GaAs}$ の融解及び成長過程の観察は NHK 放送技研 の佐藤のチームで行われている。彼らは GaAs の融解 之成長を観察するために特殊な高温炉を作製し, 実験が 行われている。すなわちその高温炉は試料加熱用カーボ ンヒータとヒ素圧制御用の巻線ヒータを有しさらに結晶 成長の様子を観察するためにカーボンヒータと試料の縦 方向の相詨的位置を外部から変えることができる密閉型 高温炉である。

Fig. 2 は HB-GaAs 結晶の融解一成長過程を捕えた ビデオトポグラフ像である。写真では黒がX線強度の強

Table 1 Experiments by using synchrotron radiation X-ray topography

\begin{tabular}{l|l}
\hline Room Temperature & $\begin{array}{l}\text { Magnetization process of } \mathrm{Fe}-3 \% \mathrm{Si}, \mathrm{GaAs}, \mathrm{Web} \mathrm{Si}, \mathrm{Laser} \text {-annealed } \mathrm{Si}, \mathrm{Quartz}, \\
\mathrm{Nb}, \mathrm{CaF}_{2}, \mathrm{Si}-\mathrm{In}, \mathrm{KDP}, \mathrm{Al}_{2} \mathrm{O}_{3}, \text { etc. }\end{array}$ \\
\hline \multirow{2}{*}{ High Temperature } & $\begin{array}{l}\text { Melting of Olivine }\left(1900^{\circ} \mathrm{C}\right) \\
\text { Melting and crystal growth of } \mathrm{GaAs}\left(1245^{\circ} \mathrm{C}\right)\end{array}$ \\
& $\begin{array}{l}\text { Melting and crystal growth of } \mathrm{Fe}-3 \% \mathrm{Si}\left(\sim 1500^{\circ} \mathrm{C}\right) \\
\text { Melting and crystal growth of } \mathrm{Sn}\left(232^{\circ} \mathrm{C}\right)\end{array}$ \\
& $\begin{array}{l}\text { Precipitation process of Oxigen in } \mathrm{Si}\left(\sim 950^{\circ} \mathrm{C}\right) \\
\text { Intermidiate Phase on Quartz }\left(573^{\circ} \mathrm{C}\right)\end{array}$ \\
& $\begin{array}{l}\text { Motion of the dislocation under stress in } \mathrm{InP}\left(\sim 450^{\circ} \mathrm{C}\right) \\
\text { Phase transition on GMO }\left(160^{\circ} \mathrm{C}\right)\end{array}$ \\
\hline \multirow{2}{*}{ Low Temperature } & Motion of the dislocation in Ice crystal $\left(-5^{\circ} \mathrm{C} \sim-20^{\circ} \mathrm{C}\right)$ \\
& Low temperature phase on $\mathrm{Fe} \mathrm{O}_{4}\left(<120^{\circ} \mathrm{K}\right)$ \\
\hline
\end{tabular}
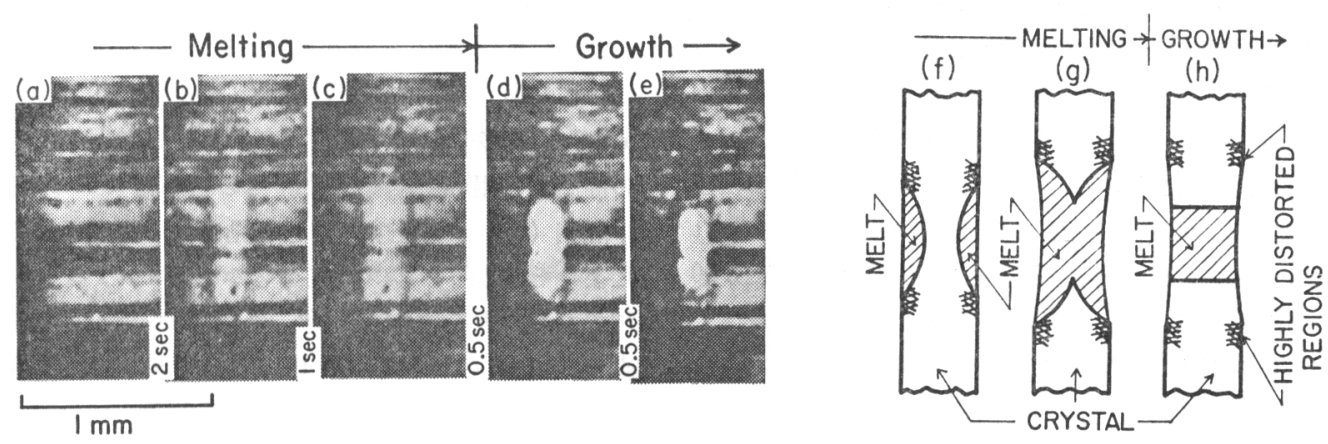

Fig. 2 (220) X-ray topography on GaAs. (a ), (b), (c) are Melting processes and (d), (e) are growth processes. (f), ( g ) and ( h) schematically show the intersection of a crystal plate at the melting and growth (by Dr. F. Sato). 

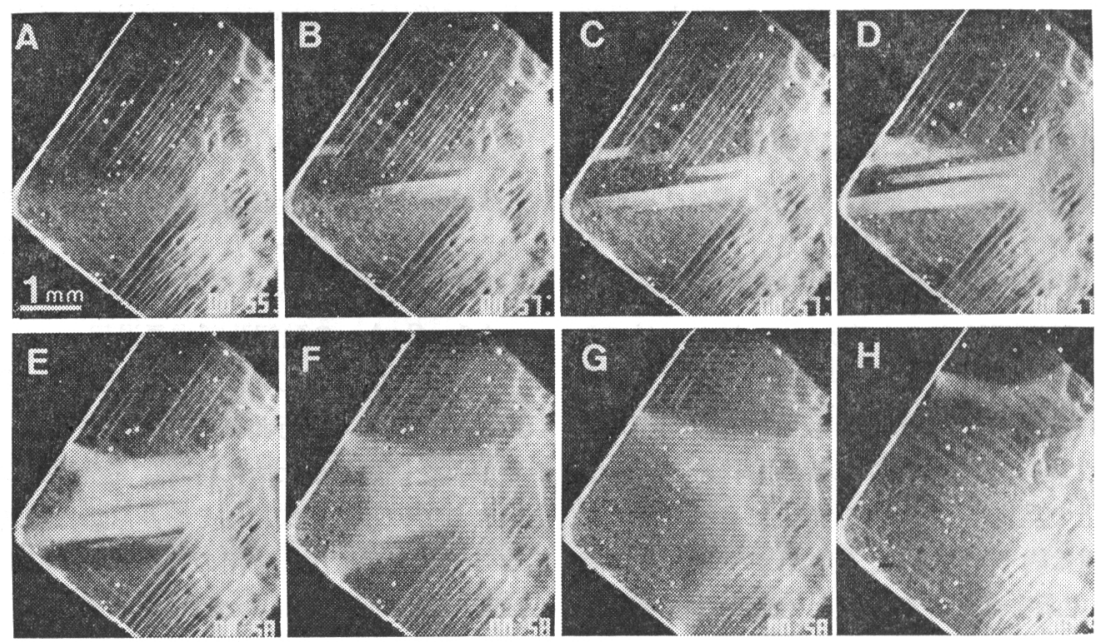

Fig. 3 (h00) X-ray topography on GMO at the phase transition temperature $\left(\sim 160^{\circ} \mathrm{C}\right)$.

いととを示している。（a）は融解直前の状態である。横 方向の黒い太い線は熱応力により発生したすべり帯であ る。（b），（c）の中央の楕円形の白い部分は融液であ る。融腋部分が白くなるのは，そてでは結晶によるブラ ッグ散乱が生じないためである。( b ) $\rightarrow(\mathrm{c})$ の融解の進 行中に注目すると, 固液界面が黒く縁どられているのが わかる。すなわち( f )，（g)で結晶断面を模式的に示す 様に融解直前の結晶表面には歪層が形成されるととが推 察される。乙の丕層は ( h ) で示す様に固化により凍結さ れるととも $(\mathrm{d}),(\mathrm{e})$ からわかる。

以上の歪層の形成については As の蒸発によるなど種 種の要因が考えられ，目下検討を進めている。また彼ら は次の様な考元を提示している。すなわち，現在 $\mathrm{GaAs}$ 単結晶育成において微小久陥の形成が問題となっている が, 実際の単結晶育成においてもミクロな融解と固化が 繰り返し起こっている。従ってての観察した歪層は微小 欠陥の形成に関連するあのであるうという考えである。

\section{2 モリブデン酸ガドリニウム（GMO）の相転移}

乙の実験は現在三洋電機筑波研究所の鈴木茂雄之筆者 を中心として行われた ${ }^{8)}$ 。放射光トポグラフィによる相 転移観察の長所, 短所を示す意味で紹介しよう。

との物質は一般に $160^{\circ} \mathrm{C}$ 付近に 1 次転移点を持ち転移 点以下では強誘電相, 以上では常誘電相を示すと言われ ている。Fig. 3 は転移点を通過する昇温過程を h 00 反射で観察したもので, 温度上昇の幅は $\mathrm{A} \sim \mathrm{H}$ 全体で $0.2 \sim 0.3^{\circ}$ である。写真 $\mathrm{A}$ で右上から左下の方向に走る シャープな平行線は強誘電分域である。温度を上げてい く之水平方向のシャープな構造が結晶中央部分から出現 し(B), 少しずつ領域を拡大し (C, D), 常誘電相の導入 をまねく(Eの左端の部分)。その後は常誘電相が拡大
していくが常に 2 つの相の間にこの構造が観察される $(F, G, H)$ 。との結果加常誘電相と強誘電相の間に何ら かの中間的な構造の存在が推定できる。との様簡単な 実験で構造のわずかに異なる 2 次構造を捕えることがで きるのは放射光トポグラフィの長所である。

しかしこの写真で判る様に結晶中央部分から相転移が 始まっている。乙れは白色X線照射によって中央部分か ら加熱されるためで, 白色卜ポグラフィを行う以上, 照 射による温度勾配から逃れられない様である。そのため 熱応力の存在をその物性解勫に加味する必要が出てくる ととになる。

この様なサンプルの温度上昇は相転移の観察に 1つの 困難さを与えている。しかしウィグラーラインのモノク ロメータ）を利用して単色トポグラフィを行うと温度上 昇が観察されず，狭い温度領域の現象む十分に観察でき ることが明らかとなった。その例を次に示そう。

\section{3 単色 X線トポグラフィ（水晶 $\alpha-\mathrm{IP}-\mathrm{B}$ 相転移へ の応用)}

この実験は名大工学部の鄉原之加藤によって進めろれ ている。彼らは主に名大超強力X線を用いて, 水晶の $\alpha \rightleftarrows \beta$ 相転移 $\left(573^{\circ} \mathrm{C}\right)$ を温度勾配の小さなトポグラフ用 の高温炉を用いて観察した。その結果約 $2 \mathrm{~K}$ の範囲に 中間相 (IP) が存在するととを見出し, 衛星反射の観察 によりそれがドメイン構造をむつインコメンシュレート 相であるととを確かめた ${ }^{1,2)}$ 。その際 $\alpha$ 相からの転移点 直上 $0.1 \mathrm{~K}$ の範囲の IP 相に扔いて編状コントラスト が出現するととがわかっている。とのテーマを放射光の 白色トポグラフィで観察すると, 照射による温度勾配の ため常に相境界を含む状態でしか観察できなかった ${ }^{10}$ 。

しかし単色X線 $(0.7 \AA$ ) で観察すると, Fig. 4 で示 


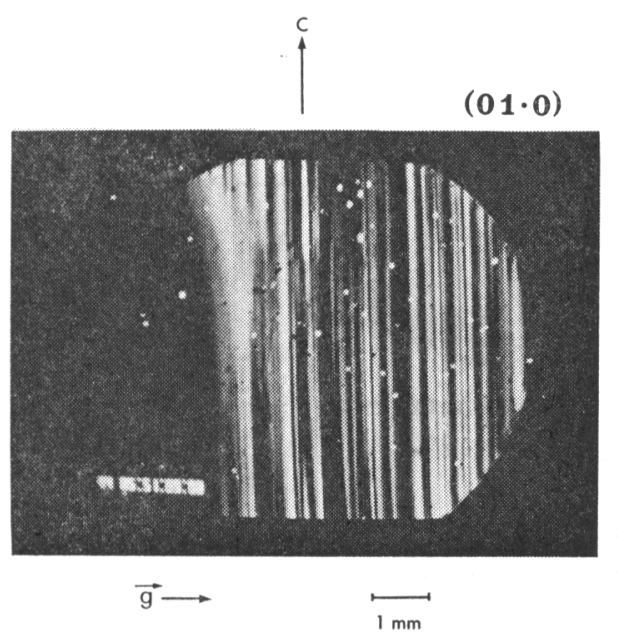

Fig. $4(0.1 \cdot 0) \mathrm{X}$-ray topography on quartz by using monochromatic X-ray $(0.7 \AA)$. The pattern of vertical stripes show that the crystal temperature is that of intermediate phase (IP) just above $\alpha$-phase (by Dr. K. Gouhara).

す様にほぼ全面が $\alpha$ 相転移点直上で観察される縞状コ ントラストのみとなっており, 試料内の温度勾配は 0.1 $\mathrm{K} / \mathrm{cm}$ 以下であるととがわかる。現時点ではとの縞構造 の詳細は明らかになっていないが単色X線トポグラフィ の利用を進めることにより明らかになることを期待して いる。

またもう 1 つの白色 X線トポグラフの問題点は高いバ ックグラウンドであるが，乙れあ少なく SN の良い像が 得られ, 弱いコントラストしか期待できない実験にも応 用されていくと考えられる。

以上, 白色X線トポグラフィを利用した GaAs の融 解と成長, GMO の相転移, そして単色X線トポグラフ ィを利用した水晶の相転移の観察例を紹介したが, その 他多くの実験が進められており，いくつかトピックス的 なむのを簡単に紹介しておてう。

“InP, GaAs の転位の生成と運動のその場観察” が NTT の東野を中心にして行われている11。彼らはトポ グラフィ観察用の高温・引っぱり装置を開発して応力歪曲線を測定しながら転位の生成過程と運動の速度の測 定を行っている。

“Fe-3\% Si の融解及び凝固過程のその場観察” が新
日鉄の松宮を中心にして行われている。彼らは $\mathrm{Fe}-3 \%$ Si の凝固過程においてデンドライト成長を観察し，そ のデンドライトの間隔と冷却速度との関係を測定してい る。

また低温トポグラフィでは, “固体ヘリウムのトポグ ラフィによる観察” が東北大学教授・鈴木秀次を中心に して進められている。白色 X線による温度上昇が眯念 されたが, 固体ヘリウムのラウエスポットの観察に成功 し, 今後の発展が期待されている。

\section{5. おわりに}

さて放射光X線トポグラフィについて記述してきた が, “表面科学”とは縁のないむのに終ってしまうかも 知れない。しかし “固体表面” の研究の第一歩は固体自 身のキャラクタリゼーションから始まるものであろう。 その立場からすれば全く無縁とむ言えないと考えてい る。とむかく, 読者にとって何らかの参考になれば幸い である。

\section{文献}

1) K. Gouhara and N. Kato: J. Phys. Soc. Jpn. 54, 1868 (1985).

2) K. Gouhara and N. Kato: J. Phys. Soc. Jpn. 54, 1882 (1985).

3) S. Suzuki, M. Ando, K. Hayakawa, O. Nittono, H. Hashizume, S. Kishino and K. Kohra : Nucl. Instr. and Meth. 227, 584 (1984).

4) J. Chikawa, F. Sato, T. Kawamura, T. Kuriyama, T. Yamashita and N. Goto: "X-ray instrumentation for Photon Factory", eds. S. Hosoya, Y. Iitaka and H. Hashizume (KTK/ Reidel, Tokyo, to be published).

5) S. Suzuki and H. Kawata : ibid.

6) K. Namikawa, M. Ando, T. Nakajima and H. Kawata: J. Phys. Soc. Jpn. 54, 4099 (1985).

7) 鈴木茂雄, 河田 洋: 日本結晶学会誌, 27,128 (1985).

8) S. Suzuki, H. Kawata and M. Ando: Photon Factory Activity Report, VI-135 (1983/1984).

9) H. Kawata and M. Ando: Nucl. Instr. and Meth. (to be published).

10) K. Gouhara and N. Kato: Photon Factory Activity Report, VI-163 (1983/1984).

11) S. Tohno, S. Shinoyama, A. Katsui and $H$. Takaoka: J. Cryst. Growth 73, 190 (1985). 